Article

\title{
Indoor Air Quality Assessment: Comparison of Ventilation Scenarios for Retrofitting Classrooms in a Hot Climate
}

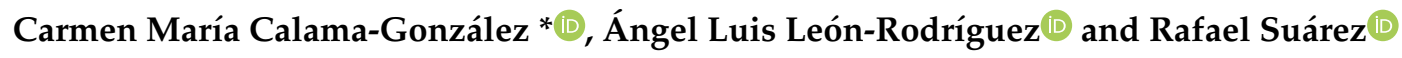 \\ Instituto Universitario de Arquitectura y Ciencias de la Construcción, Escuela Técnica Superior de Arquitectura, \\ Universidad de Sevilla, Av. Reina Mercedes 2, 41012 Seville, Spain; leonr@us.es (Á.L.L.-R.); rsuarez@us.es (R.S.) \\ * Correspondence: ccalama@us.es; Tel.: +34-954559517
}

Received: 29 October 2019; Accepted: 2 December 2019; Published: 4 December 2019

check for updates

\begin{abstract}
Current energy efficiency policies in buildings foster the promotion of energy retrofitting of the existing stock. In southern Spain, the most extensive public sector is that of educational buildings, which is especially subject to significant internal loads due to high occupancy. A large fraction of the energy retrofit strategies conducted to date have focused on energy aspects and indoor thermal comfort, repeatedly disregarding indoor air quality criteria. This research assesses indoor air quality in a school located in the Mediterranean area, with the objective of promoting different ventilation scenarios, based on occupancy patterns and carbon dioxide levels monitored on site. Results show that manual ventilation cannot guarantee minimum indoor quality levels following current standards. A constant ventilation based on $\mathrm{CO}_{2}$ levels allows $15 \%$ more thermal comfort hours a year to be reached, compared to $\mathrm{CO}_{2}$-based optimized demand-controlled ventilation. Nevertheless, the latter ensures 35\% annual energy savings, compared to a constant $\mathrm{CO}_{2}$-based ventilation, and $37 \%$ more annual energy savings over that of a constant ventilation rate of outdoor air per person.
\end{abstract}

Keywords: school buildings; indoor air quality; $\mathrm{CO}_{2}$ levels; mechanical ventilation; thermal comfort; energy consumption; Mediterranean climate

\section{Introduction}

Given that the building sector accounts for around $40 \%$ of energy consumption [1] in Europe, increasing energy efficiency in buildings has become a fundamental goal [2]. As established in Directive 2010/31/EU [3], it is crucial to reduce the energy needed to adequately cool, heat, and ventilate buildings, fostering alternative solutions that minimize energy demand [4]. Nevertheless, the slow rate at which existing buildings are being replaced by new constructions [5] makes it difficult to meet the energy savings proposed in these standards. Thus, the existing building stock must be refurbished in order to provide significant environmental effects [6]. As a result, current energy policies promote building retrofitting as a main strategic action, as established in Directive 2012/27/EU [7]. In this regard, Directive 2018/844 [8] establishes a long-term plan to enhance building retrofitting of the existing stock for its decarbonization, through high-energy efficiency measures, including aspects relating to health and air quality.

Equally, the increasing outdoor temperatures due to climate change significantly impact the energy consumption of existing buildings and frequently lead to indoor overheating [9], which negatively affects thermal comfort and indoor air quality [10]. These phenomena are more pronounced in the warmer climates of southern Europe [11], including the Mediterranean area. In addition, the educational building stock is especially sensitive to these issues given the importance of internal occupancy loads in the thermal balance. This sector is the most extensive for public buildings in 
southern Europe [12]. The Spanish educational building stock was mainly built prior to 1979 [13], predating the first standard establishing thermal requirements [14]. This stock consists of 33,667 non-university centers, and just over 7200 of these are located in southern Spain [15].

As established by Stabile et al. [16], energetically retrofitting existing buildings is key for reducing energy costs in the building sector. For this reason, retrofit strategies in the existing educational stock in Europe have fostered the implementation of consumption-saving solutions, mainly considering thermal and energy-based approaches [5]. In contrast, indoor air quality (IAQ) is usually relegated to the background, despite its direct relation to health and comfort [17].

In the case of southern Spain, the existing educational buildings do not generally have cooling systems [18], since the academic year only considers the partial use of these buildings in summer season (classes finish in mid-June and start in mid-September). It is therefore vital to promote alternative retrofit strategies that guarantee adequate IAQ during the periods of use.

Among the main IAQ indicators, carbon dioxide levels are quite widespread when assessing indoor spaces, such as educational buildings, where the main polluting source is the human metabolism [19]. Wargocki and Wyon [20] stated that both temperatures and air quality in classrooms are important factors in the learning process, and should be as much a priority as improving teaching methods. Extensive research has shown that spaces with insufficient or inadequate ventilation may lead to occupant discomfort [21], while having adverse effects on health and cognitive performance [22,23]. Moreover, poor IAQ has serious repercussions on the attendance and learning ability of students [24], reducing the performance of tasks [25,26], and leading to occupant discomfort. Shendell et al. [27] reported a statistically significant relation between student absenteeism and carbon dioxide concentrations, stating that a 1000-ppm increase in the difference between indoor and outdoor $\mathrm{CO}_{2}$ concentration led to an increase of around $10 \%$ to $20 \%$ in student absenteeism. Branco et al. [28] analyzed how the exposure to different indoor air pollutants $\left(\mathrm{CO}_{2}, \mathrm{CO}, \mathrm{HCOH}, \mathrm{NO}_{2}, \mathrm{O}_{3}\right.$, total volatile organic compounds, $\mathrm{PM}_{1}, \mathrm{PM}_{2.5}, \mathrm{PM}_{10}$, and total suspended particles) influence children's health and comfort. After monitoring 25 nursery and primary schools they concluded that $\mathrm{PM}_{2.5}$ and $\mathrm{CO}_{2}$ were the major concerning pollutants. Likewise, Becerra et al. [29] measured high priority pollutants (such as $\mathrm{CO}_{2}$, $\mathrm{PM}_{2.5}, \mathrm{PM}_{10}$, and TVOC, among others) in nine Mediterranean schools. The authors reported that the main indoor air pollutant sources were those related to occupancy and settled dust: $\mathrm{CO}_{2}$ and PM. Lazovic et al. [30] assessed $\mathrm{PM}_{10}, \mathrm{PM}_{2.5}, \mathrm{CO}_{2}$, and $\mathrm{NO}_{2}$ concentrations in two schools and identified a correlation between $\mathrm{PM}$ and $\mathrm{CO}_{2}$ concentrations.

Several guidelines and standards also consider $\mathrm{CO}_{2}$ levels to be an adequate air quality indicator in order to modulate the outdoor air flow rate and maintain adequate indoor conditions while limiting energy consumption [31,32].

Natural ventilation is one of the most effective passive strategies for improving efficiency and energy saving [33,34], since it requires no energy to operate. Gil-Baez et al. [12] assessed the effectiveness of a cross natural ventilation system in a school in southern Spain. They stated that the natural ventilation system allows primary energy savings of up to $33 \%$ compared to a mechanical ventilation system. Vivian-Dorizas et al. [35] analyzed ventilation rates and indoor air pollutants in nine naturally ventilated schools in Athens (Mediterranean climate). The authors concluded that the average ventilation rate in all schools was higher than the minimum value recommended by the standards, with $\mathrm{CO}_{2}$ concentrations also above the limit values.

In the summer of 2017 in Seville (southern Spain), outdoor temperatures exceeded $30{ }^{\circ} \mathrm{C}$ and $40{ }^{\circ} \mathrm{C}$ for $67 \%$ and $16 \%$ of the days, respectively [36]. Thus, natural ventilation is noticeably dependent on outdoor temperatures [19]. Additionally, current ventilation standards [37] require the air to be filtered in order to ensure minimum air quality levels. Hence, natural ventilation based exclusively on opening the windows is usually insufficient to guarantee adequate IAQ conditions in educational buildings, therefore making it necessary to incorporate mechanical ventilation systems. Moreover, the control of the ventilation systems is usually conditioned by users and based mainly on thermal aspects, rather than IAQ [38] conditions, while the existence of cross-ventilation is also a factor in guaranteeing 
the movement of air. Stabile et al. [39] conducted a study on the effect of natural ventilation on IAQ in several Italian classrooms. They concluded that manual airing based on subjective physical responses could not provide minimum IAQ in the classrooms during severe meteoclimatic conditions.

For this reason, mechanical ventilation and heat recovery systems are widely incorporated to achieve adequate IAQ in existing school buildings [40] and a necessary approach for buildings with a high crowding index [16]. Schibuola et al. [6] analyzed a demand-controlled ventilation system to retrofit a university library in Venice, reaching total primary energy consumption savings of up to $33 \%$ for a ground-source heat pump. Almeida [41] explained the benefits of optimized demand-controlled ventilation methods for improving IAQ in classrooms in southern Portugal, comparing a naturally cross-ventilated classroom with a mechanically ventilated one. According to the surveys collected, students prefered the IAQ of the mechanically ventilated classroom. This is because air temperatures were lower and $\mathrm{CO}_{2}$ concentrations almost never exceeded $1500 \mathrm{ppm}$, as was the case in $20 \%$ of the occupied period with natural ventilation. Stabile et al. [39] compared the IAQ and energy consumption reported by manual airing (opening windows) and a $\mathrm{CO}_{2}$-based demand-controlled ventilation system. Mechanical ventilation results showed a reduction in $\mathrm{CO}_{2}$ levels and a lower penetration of sub-micron particles. Meanwhile, manual airing showed statistical reductions in $\mathrm{CO}_{2}$ when longer airing periods were set, also leading to higher sub-micron particle infiltration from outdoors.

This paper assessed the IAQ of a monitored school with no HVAC (heating, ventilating, and air-conditioning) system, located in the Mediterranean area. $\mathrm{CO}_{2}$ levels monitored for one year were analyzed, considering real use and occupancy patterns. The main objective of this research was quantitative and comparative analysis, through the energy modelling of several ventilation scenarios selected based on the criteria established in current standards. The final aim was to ambiently retrofit the school, evaluating the impact of these scenarios on indoor operative temperatures in the classroom, when free-running conditions (without heating and cooling systems) were considered. The influence of the ventilation scenarios on electricity consumption of the systems (fans) was also assessed. The novelty of this paper is that it assessed whether it is possible to use passive mechanical ventilation systems (no thermal treatment of air) to improve IAQ conditions in Andalusian schools.

\section{Methods}

This paper presents an analysis of indoor ambient variables, combining on-site monitoring techniques and energy simulation modelling. Specifically, IAQ was assessed through the analysis of the carbon dioxide levels recorded in a school classroom in the Mediterranean climate during a whole year, extending previous research conducted as part of the same case study [36]. $\mathrm{CO}_{2}$ concentrations were analyzed in three representative periods when the classroom was occupied (winter, summer, and mid-season), and using Matlab R2017, a matrix programming for descriptive statistical analysis [42]. Moreover, for the purposes of reference, $\mathrm{CO}_{2}$ levels were also evaluated during an occupied period.

Considering the statistical results obtained, the most unfavorable occupancy pattern of a typical working day was determined, incorporating carbon dioxide levels registered in the classroom during the monitoring process. The aim of this was to evaluate the influence of three ventilation scenarios (explained in Section 2.2) on the indoor temperatures of the classroom during a typical academic year, as well as on the electricity consumption related to the ventilation systems (fans).

\subsection{Considerations for the Indoor Air Quality Analysis}

In the analysis of the case study, maximum values recommended by several standards were taken into account in order to guarantee adequate indoor air conditions. Firstly, the Spanish Standard for Thermal Installations in Buildings (RITE) [43] recommends maximum values of carbon dioxide levels according to the indoor air quality required in the building. For educational buildings (air quality: IDA 2), it is recommended that indoor $\mathrm{CO}_{2}$ levels of $500 \mathrm{ppm}$ over outdoor $\mathrm{CO}_{2}$ concentrations are maintained. 
In contrast, the American Society of Heating, Refrigerating, and Air-Conditioning Engineers (ASHRAE) [44] recommends not to exceed indoor carbon dioxide levels by over $700 \mathrm{ppm}$ above outdoor concentrations. In addition, this standard states that $\mathrm{CO}_{2}$ levels should be below $1000 \mathrm{ppm}$ in spaces with working stations with continued exposure to pollutants.

Lastly, the European Technical Report CR 1752 [45] establishes an upper limit depending on the building category, corresponding to the A category, a PPD around $15 \%$, and a ventilation rate of $10 \mathrm{l} /$ (s.person), for sedentary occupants and indoor pollution due to human metabolism. Thus, $\mathrm{CO}_{2}$ concentrations should be kept below 460 ppm over outdoor levels.

\subsection{Considerations for the Air Changes Per Hour Analysis}

After analyzing indoor air quality analysis, three ventilation scenarios were defined according to the methods established in the Spanish Standard for Thermal Installations in Buildings (RITE) [44]: (1) Indirect classification by the rate of outdoor air per person (CVp); (2) indirect classification by $\mathrm{CO}_{2}$-based constant ventilation (CV); (3) and indirect classification by $\mathrm{CO}_{2}$-based optimized demand control (VV). The first two methods are explained in RITE [44] and are determined through a constant ventilation rate.

The first method (CVp) is applied in spaces where people are considered to have a metabolic rate of around 1.2 met and where most of the indoor pollutants are due to the human metabolism. Depending on the building use, indoor air quality is defined and a specific minimum ventilation rate per person is associated to it. In the case of a school classroom, indoor air quality is defined as "IDA 2", which corresponds to a minimum ventilation rate of $12.5 \mathrm{l} / \mathrm{s} \cdot$ person. When the classroom is unoccupied, this method considers no ventilation rate. In addition, the ventilation rate obtained requires constant application when the classroom is occupied, and as a result, it overestimates ventilation necessities.

The second method (CV) is also suitable for spaces where pollution is mainly due to human biofluents. In this case, ventilation rates are determined using Equation (1):

$$
\mathrm{Q}=\mathrm{G} /\left(\Delta \mathrm{CO}_{2} \times \mathrm{E}\right)
$$

where:

Q: Calculated ventilation rate $(1 / \mathrm{s})$;

G: $\mathrm{CO}_{2}$ pollutant loads of the space (1/s.person). For a classroom, this is $19 \mathrm{l} / \mathrm{s} \cdot$ person;

$\Delta \mathrm{CO}_{2}$ : Difference between indoor and outdoor $\mathrm{CO}_{2}$ levels $\left(10^{-6} \mathrm{ppm}\right)$. For IDA 2, a value of $500 \mathrm{ppm}$ over outdoor $\mathrm{CO}_{2}$ concentrations was considered;

E: Effectiveness of the ventilation system. This parameter was fixed at 0.9

In this study, a third scenario consisting of a variation of the second method (CV) was included in the analysis (VV) in order to optimize the ventilation rate depending on the carbon dioxide levels recorded during a typical working day. Unlike the first two scenarios, VV considers a variable ventilation rate determined from indoor $\mathrm{CO}_{2}$ recorded during the monitoring of the classroom. For its calculation, Equation (1) was also applied but considering both monitored indoor and outdoor dioxide carbon concentrations. Thus, this variable method allows a better adjustment to a real monitored case study.

\subsection{Considerations for the Energy Simulation Analysis: Thermal Comfort and Electrical Consumption}

Once the geometrical, physical, and constructive characterization of the classroom was obtained [46], an energy simulation model was constructed to analyze the influence of the ventilation scenarios above on the indoor thermal performance and electricity consumption of the ventilation systems. Neither air heat treatment nor heat recovery systems were considered for the ventilation design. Thermal comfort was assessed considering operative temperatures (both indoor air and 
surface temperatures) in the simulation model, which incorporated the calculation procedure of ISO 7726:2002 [47].

For the modelling phase, the energy analysis software Design Builder (v. 4.7.0.027), recognized by the US DOE [48], was used as an interface to EnergyPlus [49]. The adjacent spaces of the classroom were also modelled in order to account for their thermal influence. The data from the outdoor variables monitored during the year were incorporated into the weather file used for the energy simulations. Indoor air measurements during an unoccupied period in the monitoring stage were used to validate the energy simulation model following the criteria established in the American Society of Heating, Refrigerating, and Air-Conditioning Engineers (ASHRAE) Guideline 14-2002 [45].

For the thermal comfort assessment, simulated indoor temperatures were analyzed according to ISO 7730:2005 [50], considering the classroom occupied in free-running conditions (no cooling or heating system). This standard establishes a method based on the theory formulated by Fanger [51], determining a reference temperature band according to the seasonal clothing level, air humidity and velocity, activity levels, and a specific predicted percentage of dissatisfied (PPD).

Even though several formulations on the adaptive approach (such as CEN EN 15251:2007 [32], and its revision prEN 16798-1:2015 [52], or ASHRAE 55:2017 [53]) have been developed in recent decades, revealing a correlation between indoor and outdoor temperatures, these adaptive models can only be applied with a given outdoor temperature range.

Fanger's method was considered in the case study since it best reproduces the real metabolic rate and thermal resistance values recorded in the classroom [36]. In addition, as stated in the introduction, the upper limits of the outdoor temperature ranges established in the adaptive standards cited were dramatically exceeded in Seville in 2017. Thus, adaptive models could not be properly implemented in this case study.

Hence, in order to determine the thermal comfort band, the following aspects were considered: An average relative humidity of 50\%, a metabolic rate of 1.2 met, an interior PPD below $15 \%$, and a thermal resistance of 0.5 clo in summer and 1.2 clo in winter and mid-season. Thus, the thermal comfort bands were $16.1{ }^{\circ} \mathrm{C}$ to $24.1^{\circ} \mathrm{C}$ for winter and mid-season and $22.8^{\circ} \mathrm{C}$ to $26.8^{\circ} \mathrm{C}$ for summer.

When assessing the electricity consumption of ventilation systems, a fan capable of working both at a constant and a variable ventilation rate was introduced into the simulation software. A high-performance, low-consumption, and helicon-centrifuge fan was selected, meeting the requirements of the minimum ventilation rates obtained in the calculations (Section 4.3). For each scenario, the operating schedule of the fan was implemented in the energy simulation model, and based on the technical sheets of the product, the corresponding electricity consumption was assigned to each ventilation rate obtained in the calculations [54].

\section{Case Study}

\subsection{Case Study Description}

In order to conduct this research, on-site measurements were obtained for a public educational building, Martíñez Montañés Secondary School, managed by the Andalusian Regional Government. This building is located at latitude $37.37^{\circ} \mathrm{N}$ and longitude $-5.97^{\circ} \mathrm{W}$, that is, in southern Spain, in an area with a Mediterranean climate. A south-facing classroom on the second floor of the school was monitored specifically (Figure 1 ).

The $6.95 \mathrm{~m} \times 6.85 \mathrm{~m}$ classroom has four windows, which are roughly south facing. The windows, which are $2.40 \mathrm{~m}$ high and $1.40 \mathrm{~m}$ wide, account for $53 \%$ of the façade surface.

Table 1 shows the constructive and physical properties of the classroom analyzed. The infiltration rate was obtained using a Blower Door test, conducted to characterize the airtightness of the building's envelope, following the procedure established in ISO 9972:2015 [55]. The test results showed that the air leakage rate at $50 \mathrm{~Pa}$ was $\mathrm{V}_{50}=578( \pm 0.2 \%) \mathrm{m}^{3} / \mathrm{h}$ [47]. The Persily-Kronvall model was adopted [56] to convert to infiltration rates expressed in air changes per hour $(\mathrm{ACH})$. 


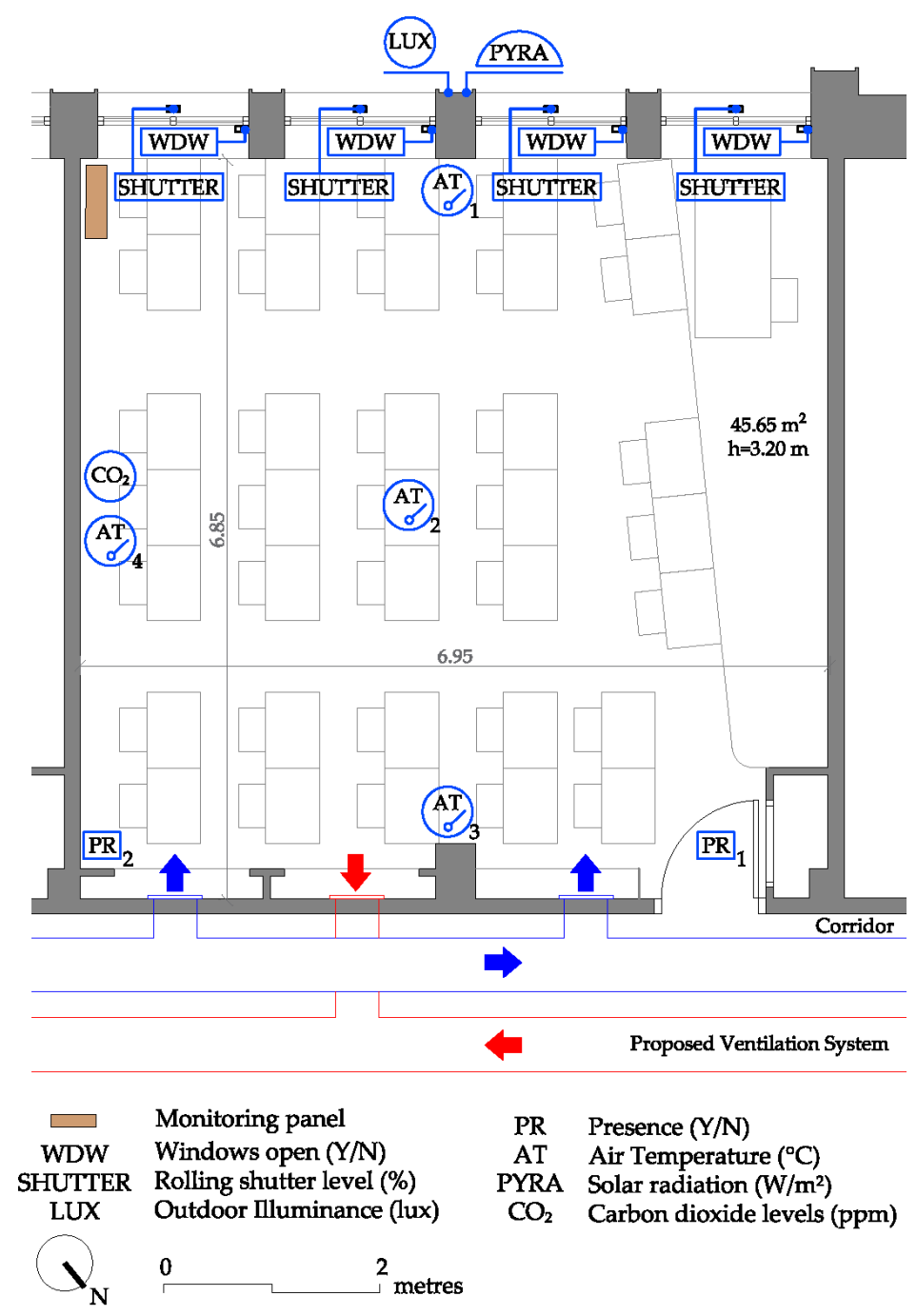

Figure 1. Floor plan of the monitored classroom with the location of the sensors used and the elements of the proposed ventilation system (explained in Section 4.3).

Table 1. Considerations for the energy simulation model.

\begin{tabular}{ccc}
\hline Variable & Value & Unit \\
\hline $\begin{array}{c}\text { Façade: } 0.015 \mathrm{~m} \text { exterior mortar rendering, 0.115 m perforated brick wall, } 0.015 \mathrm{~m} \\
\text { interior mortar rendering, 0.07 m non-ventilated air chamber, } 0.06 \mathrm{~m} \text { partition } \\
\text { brick wall and 0.015 m gypsum plaster }\end{array}$ & 1.32 & $\mathrm{~W} / \mathrm{m}^{2} \cdot \mathrm{K}$ \\
\hline $\begin{array}{c}\text { Partition wall: } 0.015 \mathrm{~m} \text { gypsum plaster, } 0.07 \mathrm{~m} \text { partition brick wall and } 0.015 \mathrm{~m} \\
\text { gypsum plaster }\end{array}$ & 1.92 & $\mathrm{~W} / \mathrm{m}^{2} \cdot \mathrm{K}$ \\
\hline $\begin{array}{c}\text { Floor/ceiling: } 0.02 \mathrm{~m} \text { artificial stone floor, } 0.025 \mathrm{~m} \text { mortar rendering, } 0.30 \mathrm{~m} \\
\text { ceramic beam filling pieces and 0.015 m gypsum plaster }\end{array}$ & 1.29 & $\mathrm{~W} / \mathrm{m}^{2} \cdot \mathrm{K}$ \\
\hline Windows: aluminum frame, 4 mm single glazing, no thermal bridge & 5.70 & $\mathrm{~W} / \mathrm{m}^{2} \cdot \mathrm{K}$ \\
\hline Infiltration rate & 0.40 & $\mathrm{ACH}$ \\
\hline Occupancy rate & 0.45 & $\mathrm{p} / \mathrm{m}^{2}$ \\
\hline
\end{tabular}

Lessons in the school are taught in the morning (from 9:00 to 15:00) for secondary education, and in the evening (from 16:00 to 20:00) for adult education. Although the classroom has a maximum capacity of 35 students plus a teacher (Figure 2a), the maximum number of occupants during the monitoring process was 21 people (occupancy rate of $0.45 \mathrm{p} / \mathrm{m}^{2}$ ). The academic year for the school 
considers the following no-work periods: Until 8 January; from 23 June to 17 September; and from 20 December. Moreover, the classroom has an external solar protection system (Figure $2 b$ ) from its original construction, based on roller blinds made of polyvinyl chloride material (PVC).

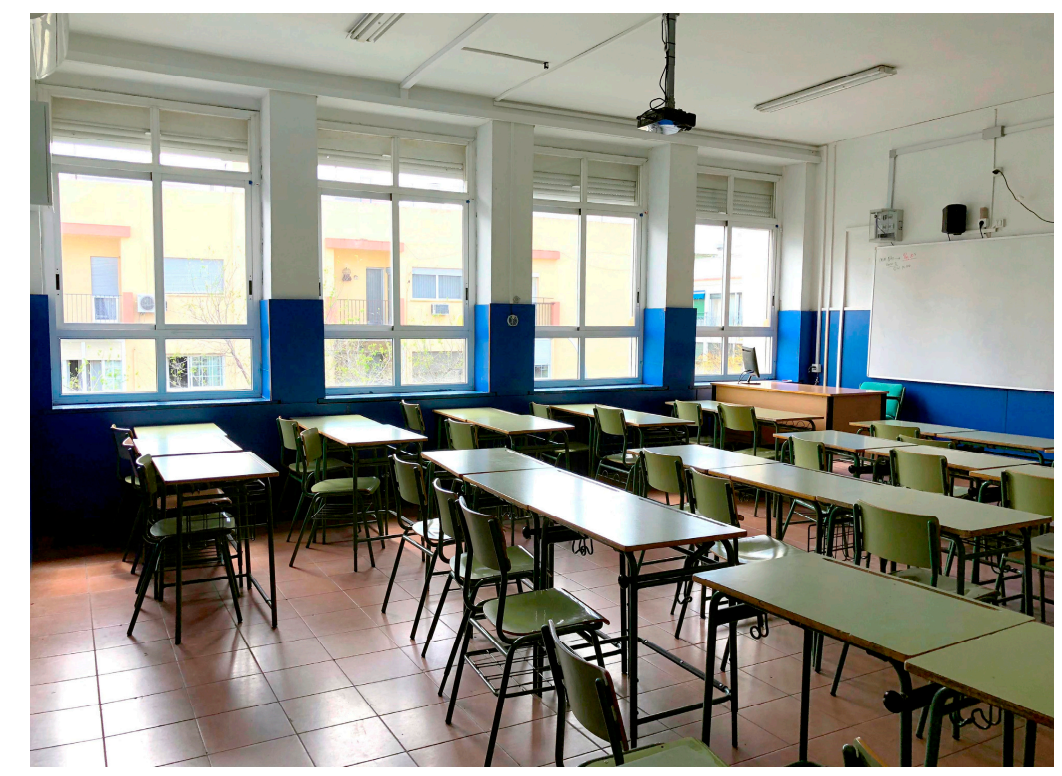

(a)

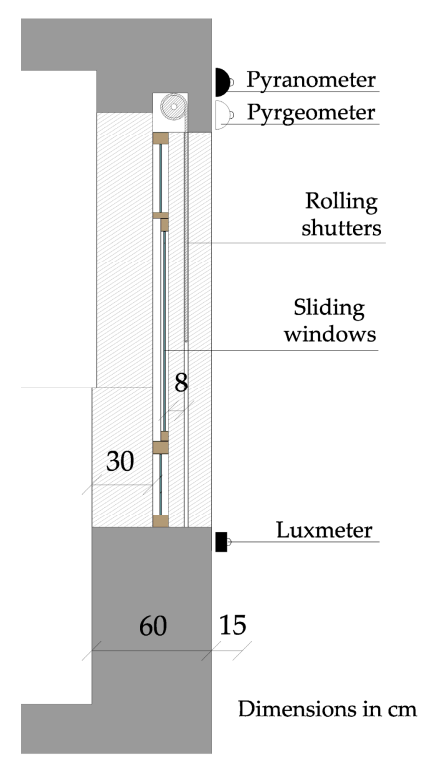

(b)

Figure 2. (a) Monitored classroom; (b) Cross-section of the window: location of outdoor sensors.

\subsection{Monitoring System}

The monitoring system, installed according to EN ISO 7726:2002 [47], consists of the sensors indicated in Table 2, also showing their main technical characteristics. This equipment registers information at 10-min intervals, storing it on data loggers located in the monitoring panel of the classroom. Every $30 \mathrm{~min}$, the monitored data is uploaded to a File Transfer Protocol (FTP) server through a mobile card.

Table 2. Probes in the room monitored.

\begin{tabular}{cccccc}
\hline Device & $\mathbf{N}^{\mathbf{0}}$ & Location & Unit & Range & Accuracy \\
\hline $\mathrm{CO}_{2}$ detector & 1 & On surface: east Wall & $\mathrm{ppm}$ & $0-2000$ & $\begin{array}{c} \pm(40 \mathrm{ppm}+4.8 \% \\
\text { of reading })\end{array}$ \\
\hline Presence detector & 2 & North walls & $\mathrm{Y} / \mathrm{N}$ & $4-15 \mathrm{~m}$ & - \\
\hline Window opening control & 4 & Windows & $\mathrm{Y} / \mathrm{N}$ & - & - \\
\hline Blind level sensor & 4 & Blinds & $\mathrm{mm}$ & $200-8000$ & $\pm 25 \mathrm{~mm}$ \\
\hline Pyranometer & 1 & Outdoor & $\mathrm{W} / \mathrm{m}^{2}$ & $0-4000$ & $\pm 2.0 \%$ \\
\hline Lux meter & 1 & Outdoor & lux & $0-200,000$ & $\pm 4.0 \%$ \\
\hline
\end{tabular}

The data loggers store information related to several sensors. There is an indoor sensor for carbon dioxide levels in the classroom, as well as two presence sensors, four sensors that measure the aperture of the window, and another four sensors that register information of the shutter aperture levels. It should be noted that the monitoring system only registers the aperture or closure of each window $(\mathrm{Y} / \mathrm{N})$ : $100 \%$ means that all the windows are open. However, no information is provided on the percentage of the aperture of the window or the associated ventilation rate. An outdoor luxmeter and pyranometer were installed on the façade in addition to the indoor sensors.

Information regarding other outdoor ambient variables was also recorded (relative humidity, air temperature, $\mathrm{CO}_{2}$ levels, wind speed and direction) by a local weather station, placed in some 
test cells [57], at a distance of $450 \mathrm{~m}$ from the educational building. Table 3 shows the technical characteristics of the sensors in the weather station.

Table 3. Probes in the weather station.

\begin{tabular}{cccccc}
\hline Device & $\mathbf{N}^{\mathbf{0}}$ & Orientation & Unit & Range & Accuracy \\
\hline Thermometer & 2 & $\mathrm{~N}$ & ${ }^{\circ} \mathrm{C}$ & $-40-80$ & $\pm 0.15 \pm 0.1 \%$ \\
\hline Hygrometer & 1 & - & $\%$ & $0-100$ & $\pm 3 \%(0.70 \%)- \pm 5 \%(71.10 \%)$ \\
\hline $\mathrm{CO}_{2}$ detector & 1 & - & $\mathrm{ppm}$ & $0-2000$ & $\pm 2.0 \%$ \\
\hline Anemometer & 1 & - & $\mathrm{m} / \mathrm{s}$ & $0-50$ & \pm 0.5 \\
\hline Vane & 1 & - & $\circ$ & $0-360$ & \pm 2.5 \\
\hline
\end{tabular}

Information registered by all outdoor sensors was included in the weather file used in the energy simulation modelling. Air temperatures monitored inside the classroom during an unoccupied period when the shutters are fully open were used to validate the energy simulation model, as explained in Section 2.3.

\subsection{Monitoring Phases}

The classroom was monitored from May 2017 to April 2018 (12 months), recording data during three representative seasonal periods: Winter, summer, and mid-season. The characteristics of these periods are shown in Table 4.

Table 4. Characteristics of periods analyzed.

\begin{tabular}{ccccc}
\hline Periods & Description & $\mathbf{T}_{\text {out }}\left({ }^{\circ} \mathbf{C}\right)$ & Hours Analyzed & Occupied Hours \\
\hline Winter & 1 December to 28 February & $1.9-26.2$ & 2160 & 964 \\
\hline Summer & 1 May to 23 June & $9.4-46.4$ & 1296 & 335 \\
\hline Mid-season & 1 March to 30 April & $5.2-36.5$ & 1464 & 429 \\
\hline \multicolumn{5}{c}{ Note: Non-working days have been removed from the winter period. }
\end{tabular}

In the statistical analysis of the periods, the following non-working days were erased from the study: From 20 December to 8 January and from 23 June to 17 September. Thus, the analysis conducted is in line with the academic year of the educational building.

For reference, a 120-hour unoccupied period (18 to 22 April) was also considered in order to collect indoor $\mathrm{CO}_{2}$ values without the influence of users.

\section{Analysis of Results}

Indoor carbon dioxide levels during unoccupied and occupied periods were assessed in order to verify whether IAQ conditions meet the requirements and recommendations of the standards. The ventilation scenarios considered, determined based on the $\mathrm{CO}_{2}$ concentrations obtained, are then shown. Finally, the influence of each ventilation scenario on indoor temperatures and electricity consumption of the ventilation system was evaluated.

\subsection{Carbon Dioxide Levels Analysis: Unoccupied Period}

Figure 3 shows the average carbon dioxide concentrations in the classroom during an unoccupied period and with the windows totally closed. As can be seen, average outdoor $\mathrm{CO}_{2}$ levels of around $470 \mathrm{ppm}$ were registered, with maximum values of $530 \mathrm{ppm}$. Inside the classroom, average $\mathrm{CO}_{2}$ levels of 390 ppm were recorded, with minimum and maximum peaks of 376 and $421 \mathrm{ppm}$, respectively. Carbon dioxide levels were maintained between 350 and 400 ppm during $70 \%$ of the total hours. The rest of the time, values varied between 400 and $450 \mathrm{ppm}$. 


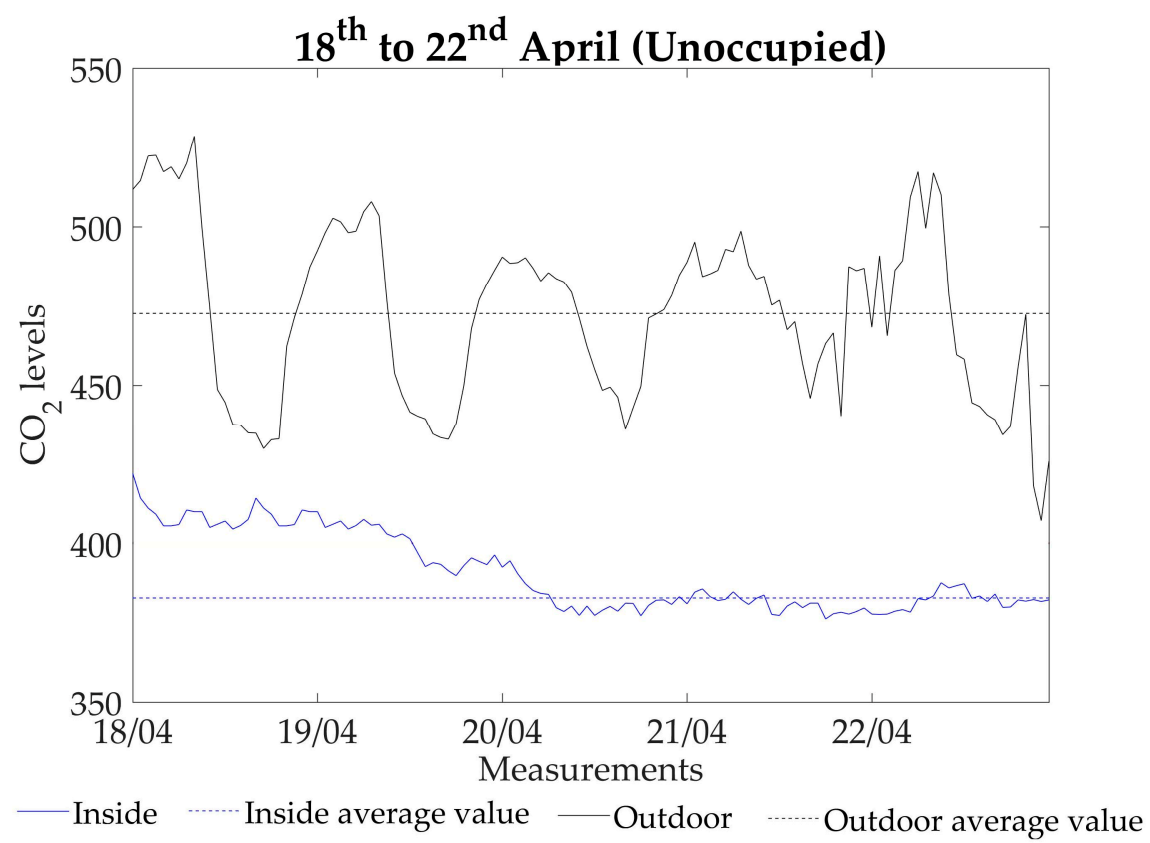

Figure 3. Carbon dioxide levels $\left(\mathrm{CO}_{2}\right)$ recorded inside the classroom during the unoccupied period (18 April to 22 April). Windows were totally closed.

The relatively high indoor concentration of $\mathrm{CO}_{2}$ during this period may be attributed mainly to the closure of the windows and the absence of a mechanical ventilation system in the classroom. Moreover, it should be taken into consideration that the reduction of dioxide carbon levels was progressive. This is easily observed in Figure 3, where $\mathrm{CO}_{2}$ concentrations are slightly higher during the first two days after an occupied period (18 April and 19 April) and are then noticeably reduced (from 20 April to 22 April).

\subsection{Carbon Dioxide Levels Analysis: Occupied Periods}

Figure 4 shows the percentage of hours when the classroom was: (1) Unoccupied, (2) occupied in free-running conditions (without heating and cooling systems), and (3) occupied in thermal comfort (according to ISO 7730:2005) during free-running conditions. In these three cases, the percentages indicated were determined considering $100 \%$ of the hours. Figure 5 shows indoor $\mathrm{CO}_{2}$ levels registered in the classroom during the three seasonal periods analyzed and under two hypotheses: (1) Occupied and (2) occupied in thermal comfort (according to ISO 7730:2005). The ranges used to analyze carbon dioxide levels were set considering the following criteria: (1) Values under $500 \mathrm{ppm}$, which is the lower limit established by the Spanish standard (RITE) [44]; (2) values between 500 and 1000 ppm, which make it possible to identify the hours when the classroom meets the recommendations of the RITE and the RC 1752; (3) maximum values recommended by the ASHRAE, which can be assessed in the range 1000-1500 ppm; and (4) IAQ is considered to be absolutely inadequate when values are over $1500 \mathrm{ppm}$.

In summer, the percentage of occupied hours in comfort, when free-running conditions are considered, corresponds to $100 \%$ of the hours occupied in free-running conditions. This is due to the fact that the summer season analyzed is 1 May to 23 June, since these are the working summer months considered in the academic year. However, it is worth highlighting that the classroom is in thermal comfort during less than $5 \%$ of the occupied hours in free-running conditions during winter. The results obtained show that most of the time when thermal comfort is met during the winter season, carbon dioxide levels are over $1500 \mathrm{ppm}$. In mid-season and summer, $\mathrm{CO}_{2}$ levels are usually up to 1000 ppm during comfort hours. 


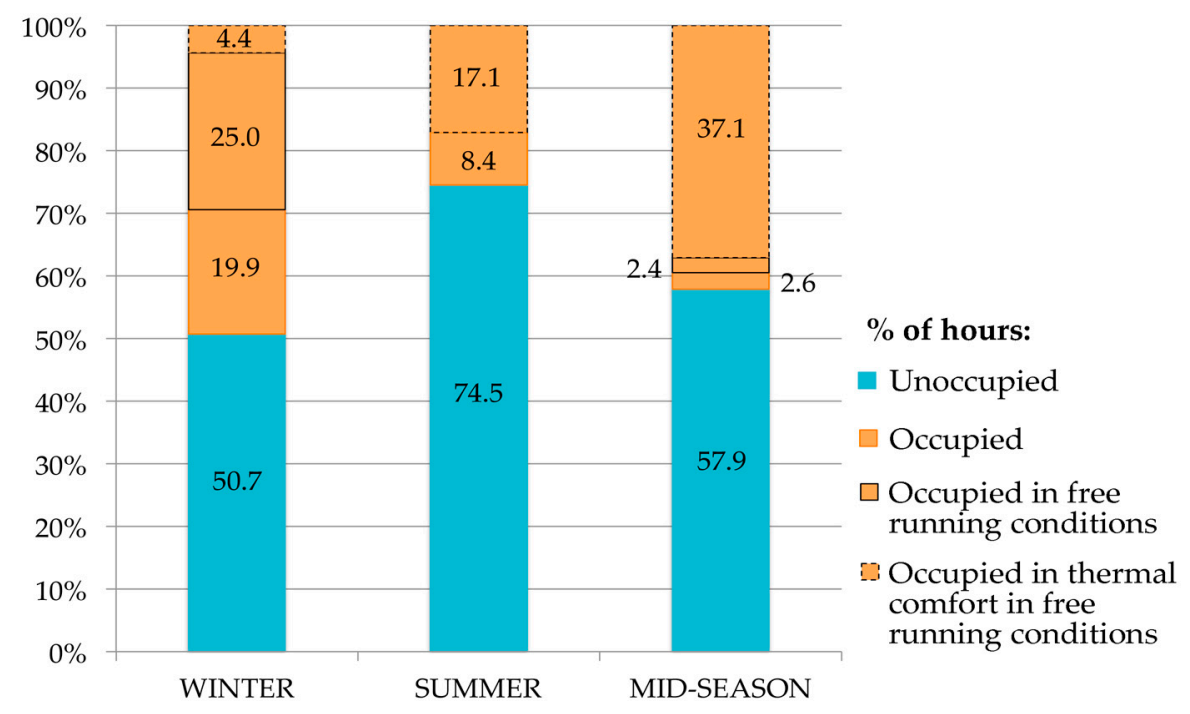

Figure 4. Occupancy pattern in the monitored classroom: \% of unoccupied and occupied hours, $\%$ of occupied hours in free-running conditions (no HVAC systems), and \% of occupied hours in thermal comfort (ISO 7730:2005) in free-running conditions.

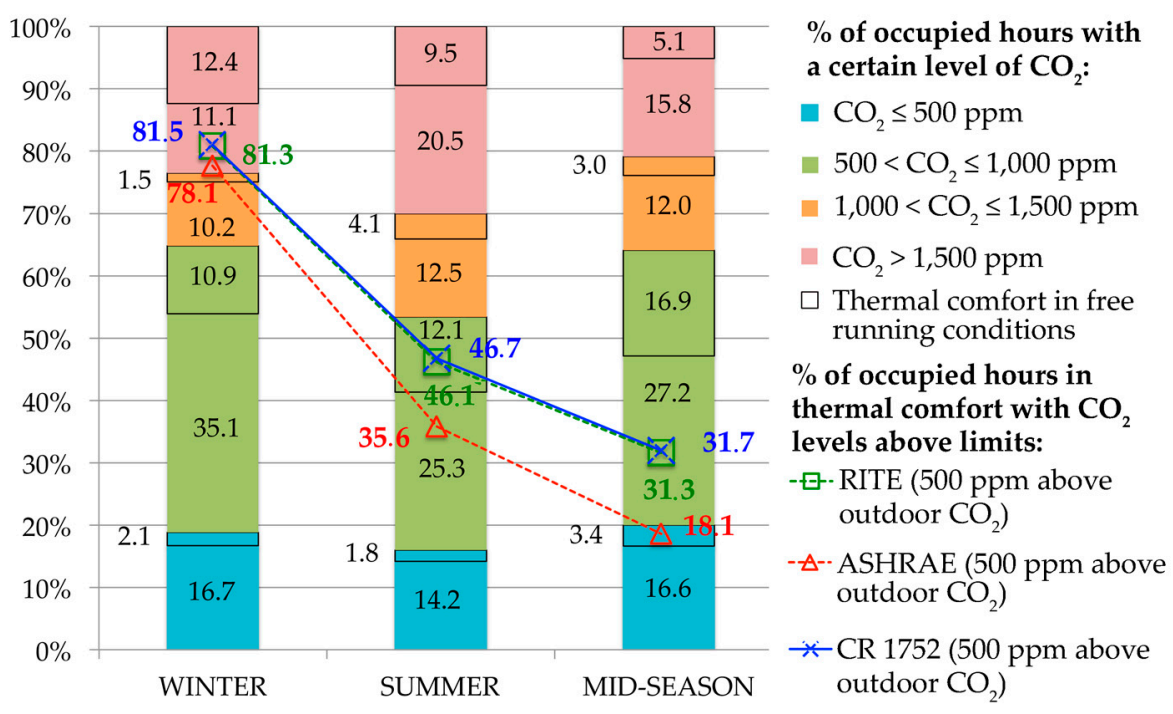

Figure 5. Percentage of hours with a given $\mathrm{CO}_{2}$ concentration registered during occupied hours and comfort hours (ISO 7730:2005) in free-running conditions (no HVAC). Percentage of hours when the $\mathrm{CO}_{2}$ recommendations of RITE, ASHRAE, and CR 1752 are exceeded.

Nevertheless, it should be taken into account that indoor $\mathrm{CO}_{2}$ levels are highly conditioned by window aperture, which is freely operated by users. For this reason, information regarding window operation is included in Table 5, establishing a correlation between this variable and the carbon dioxide concentrations registered. The information corresponds to the percentage of windows that are open: $100 \%$ means all the windows are open. The percentage of windows open with a minimum shutter aperture level of $10 \%$ is shown in parentheses. 
Table 5. Percentage of windows open during different indoor $\mathrm{CO}_{2}$ ranges and when shutters are $10 \%$ open. The highest \% is shown in bold.

\begin{tabular}{|c|c|c|c|c|}
\hline \multicolumn{2}{|c|}{ Variables } & \multirow{2}{*}{$\begin{array}{c}\text { Winter } \\
58.4(18.8)\end{array}$} & \multirow{2}{*}{$\begin{array}{c}\text { Summer } \\
74.5(63.3)\end{array}$} & \multirow{2}{*}{$\begin{array}{c}\text { Mid-Season } \\
66.2(38.4)\end{array}$} \\
\hline$\%$ of the windows that are & $\mathrm{CO}_{2} \leq 500 \mathrm{ppm}$ & & & \\
\hline $\begin{array}{l}\text { open at a certain level of } \\
\mathrm{CO}_{2} \text { (among them, \% of }\end{array}$ & $500<\mathrm{CO}_{2} \leq 1000 \mathrm{ppm}$ & $22.6(7.5)$ & $11.3(6.3)$ & $18.5(10.1)$ \\
\hline hours when shutters are & $1000<\mathrm{CO}_{2} \leq 1500 \mathrm{ppm}$ & $5.7(1.6)$ & $5.0(2.2)$ & $6.7(2.8)$ \\
\hline$\geq 10 \%$ open) & $\mathrm{CO}_{2}>1500 \mathrm{ppm}$ & $13.3(3.0)$ & $9.2(5.6)$ & $8.6(5.0)$ \\
\hline
\end{tabular}

Note: Numbers in bold represent the highest values obtained in each seasonal period.

The indoor $\mathrm{CO}_{2}$ levels observed are quite high, since the window aperture time is significantly limited, and moreover, it tends to match the low rolling shutter aperture levels.

Figures 6-8 show indoor (in blue) and outdoor (in red) $\mathrm{CO}_{2}$ levels registered in winter, summer, and mid-season. For the sake of clarity, only two weeks of each period were graphically represented. Maximum $\mathrm{CO}_{2}$ concentrations recommended by RITE (dashed purple line), ASHRAE (dashed green line), and CR 1752 (dashed yellow line) are indicated, considering the explanations provided in Section 2.1. Non-working days (in this case, unoccupied days on weekends) are shaded in grey.

Generally, in all three seasonal periods analyzed, outdoor $\mathrm{CO}_{2}$ concentrations are in the region of $500 \mathrm{ppm}$, although levels above this value are also recorded occasionally. The percentage of occupied hours in thermal comfort conditions when the maximum recommended values of the standards are exceeded is high in winter (more than $75 \%$ of the total hours). In summer and mid-season, $\mathrm{CO}_{2}$ values are above the recommended limits during $35 \%$ and $20 \%$ of the hours, respectively. During these periods, the differences between ASHRAE and the remaining two standards are greater. These differences are approximately $10 \%$ and $13 \%$ of hours in the summer and mid-season and are due to fluctuations of the outdoor $\mathrm{CO}_{2}$ levels.

Taking into account the limit values of the standards analyzed, the recommendations of RC 1752 are exceeded during a higher percentage of hours, followed by RITE and, lastly, ASHRAE, which is the most permissive standard.

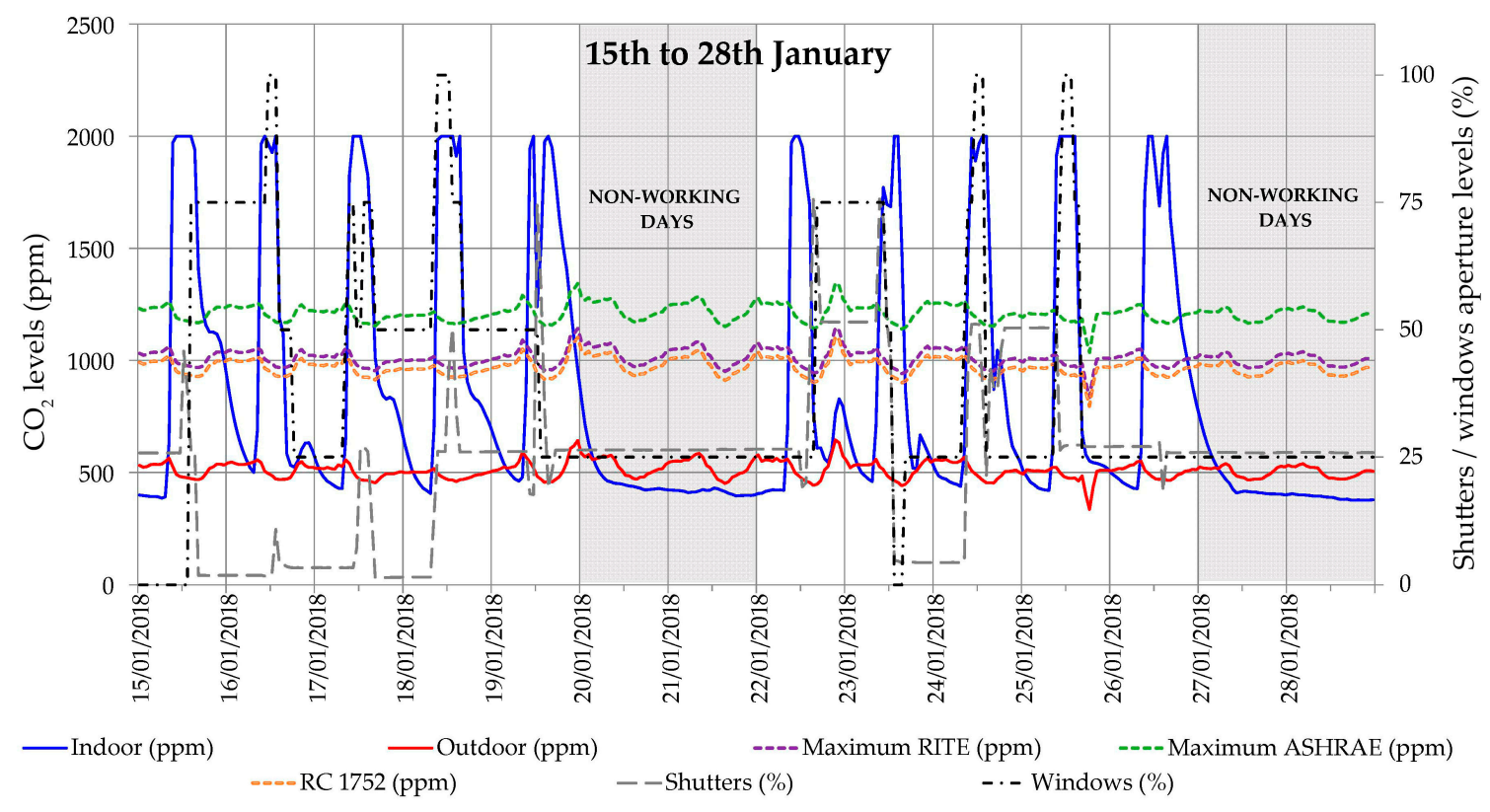

Figure 6. Indoor and outdoor $\mathrm{CO}_{2}$ levels monitored during two weeks in winter. Shutter and window aperture levels and maximum values recommended by RITE, ASHRAE, and RC 1752. 


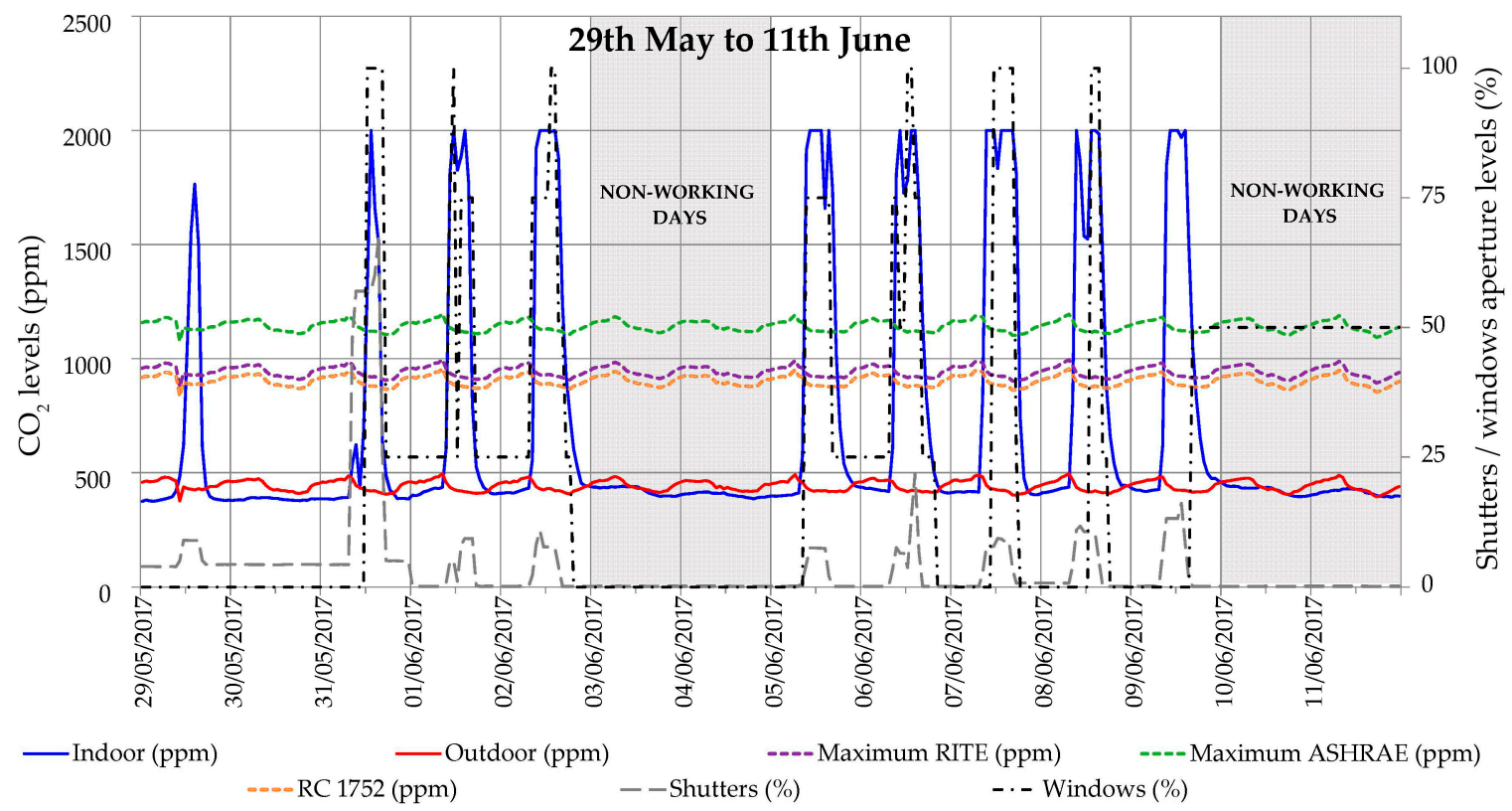

Figure 7. Indoor and outdoor $\mathrm{CO}_{2}$ levels monitored during two weeks in summer. Shutter and window aperture levels and maximum values recommended by RITE, ASHRAE, and RC 1752.

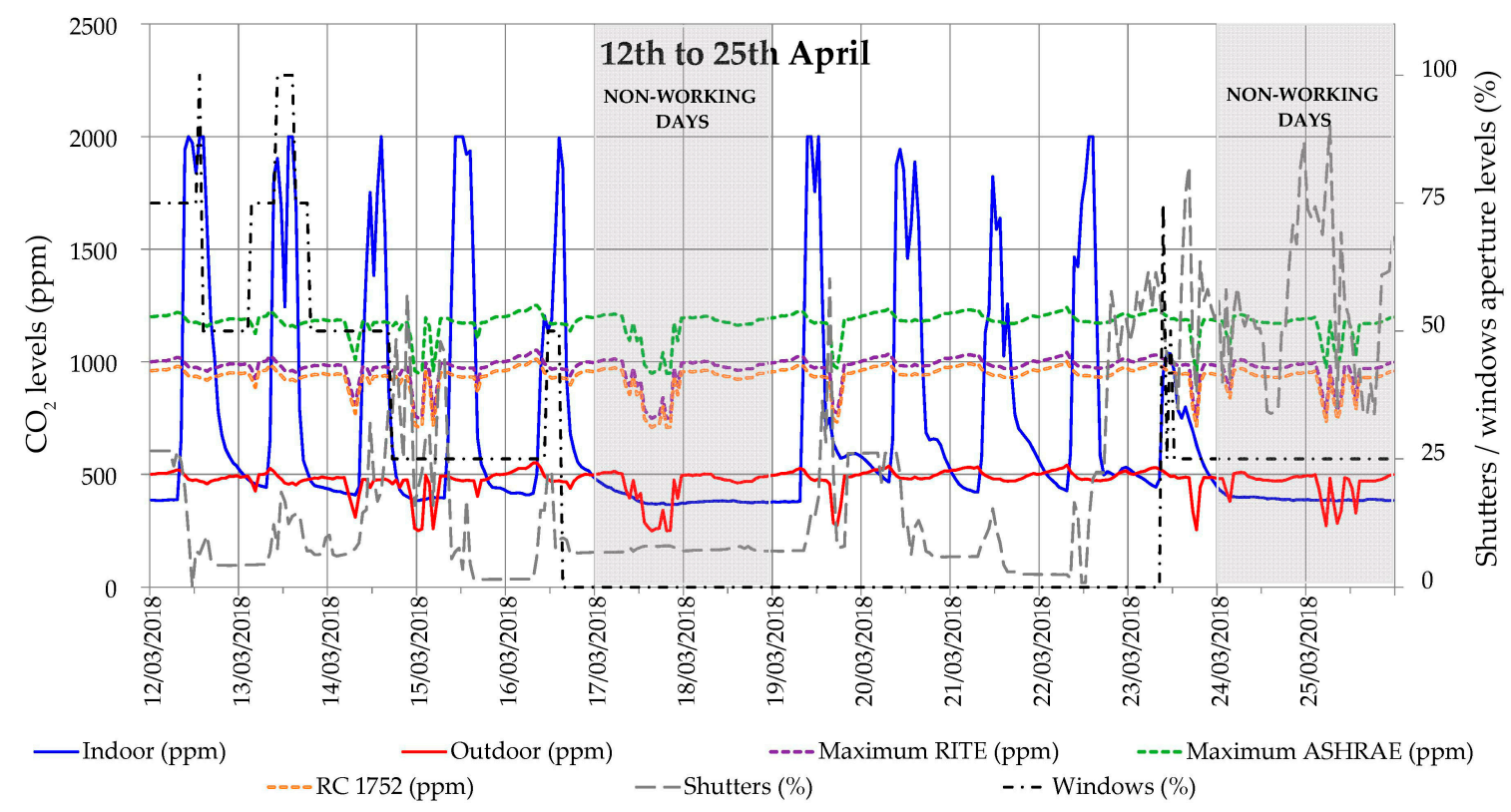

Figure 8. Indoor and outdoor $\mathrm{CO}_{2}$ levels monitored during two weeks in mid-season. Shutter and window aperture levels and maximum values recommended by RITE, ASHRAE, and RC 1752.

\subsection{Ventilation Scenarios: Air Changes Per Hour Analysis}

From the statistical analysis conducted in the previous sections, carbon dioxide concentrations monitored during a representative typical day in the classroom were obtained, considering the following criteria: (1) The classroom is unoccupied during the day before the one selected; and (2) during the day selected, windows are totally closed and the classroom is constantly occupied, with the highest number of occupants registered in the academic year: 21 people in the morning (from 9:00 to 15:00) and 25\% less people in the evening (16:00 to 20:00).

Considering the above, 19 March was selected as the representative typical day, corresponding to the mid-season period. For this day, $\mathrm{CO}_{2}$ levels, both indoors (blue line) and outdoors (black line), are 
shown in Figure 9. According to the procedure detailed in Section 2.2, the minimum ventilation rates (expressed in air changes per hour $(\mathrm{ACH})$ ) needed to reduce $\mathrm{CO}_{2}$ concentrations were determined.

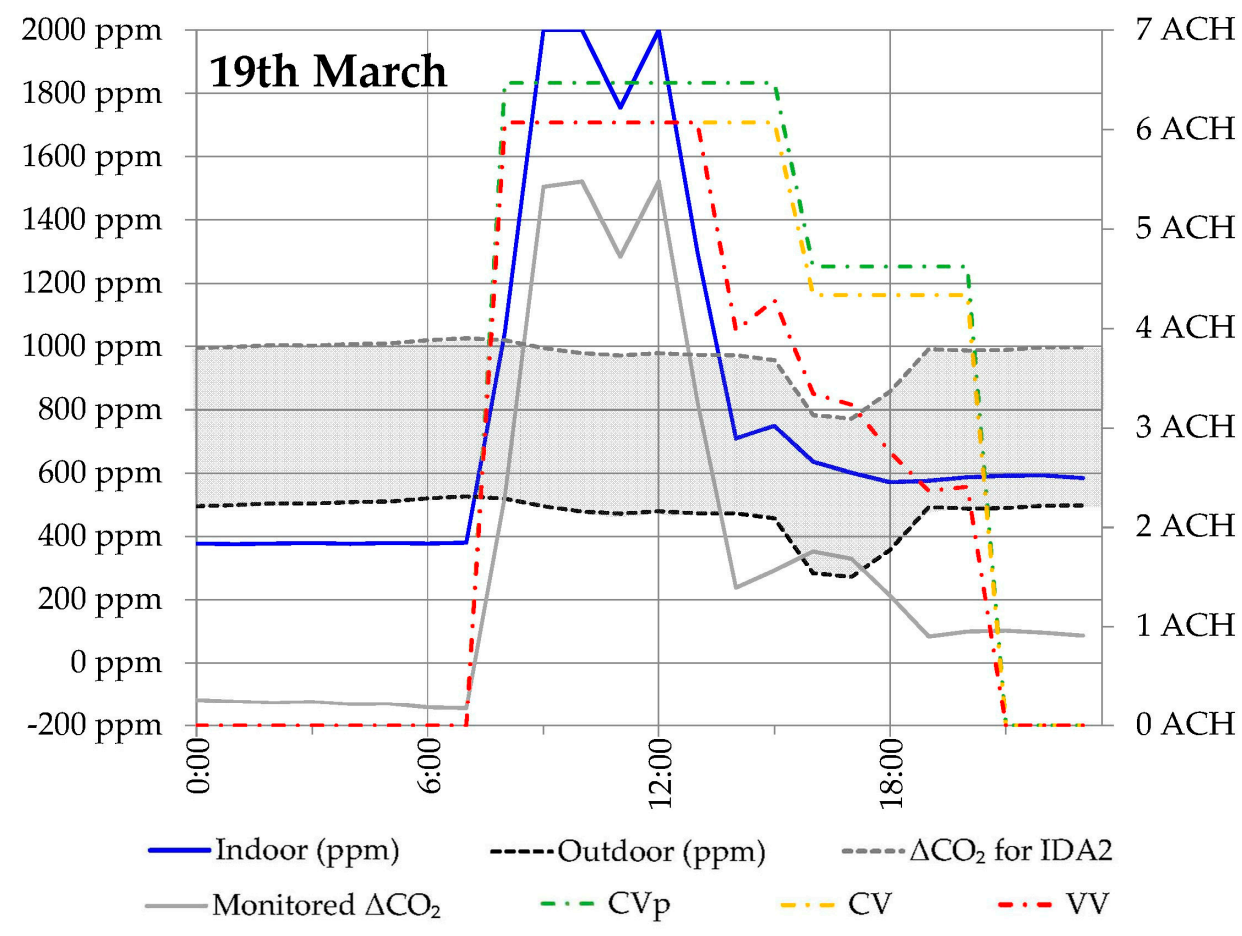

Figure 9. Indoor and outdoor $\mathrm{CO}_{2}$ levels monitored in the classroom on 19 March (no mechanical ventilation systems). The air changes per hour calculated for the simulation considerations for the three analyzed ventilation scenarios are also represented.

Table 6 shows the characteristics of each ventilation scenario when considering the specific case study, as well as the ventilation rate obtained in the calculations. The indirect classification by the rate of outdoor air per person $(\mathrm{CVp})$ is represented by a dashed green line. A minimum ventilation constant rate of $6.5 \mathrm{ACH}$ was obtained, when considering 21 people inside the classroom (as previously explained, this is the highest number of occupants registered in the academic year). This ventilation rate has to be maintained constantly during the occupied period from 8:00 to 15:00. After this, due to the $25 \%$ reduction in the number of occupants, the constant ventilation rate is set at $4.7 \mathrm{ACH}$ from 16:00 to 20:00.

Table 6. Ventilation scenarios' characteristics and calculation results.

\begin{tabular}{ccccc}
\hline Scenario & Type of Ventilation Rate & Method & Criteria & Calculated Rate \\
\hline $\mathrm{CVp}$ & Constant & People & $\begin{array}{c}\text { Standard } \\
\text { requirements }\end{array}$ & $\begin{array}{c}\text { 6.5 ACH (8:00 to 15:00) } \\
\text { 4.7 ACH (16:00 to 20:00) }\end{array}$ \\
\hline $\mathrm{CV}$ & Constant & $\mathrm{CO}_{2}$ & $\begin{array}{c}\text { Standard } \\
\text { requirements }\end{array}$ & $\begin{array}{c}\text { 6.1 ACH (8:00 to 15:00) } \\
\text { 4.6 ACH (16:00 to 20:00) }\end{array}$ \\
\hline $\mathrm{VV}$ & Variable & $\mathrm{CO}_{2}$ & Monitored data & $\begin{array}{c}\text { 3.3-6.1 ACH (8:00 to 15:00 } \\
\text { and 16:00 to 20:00) }\end{array}$ \\
\hline
\end{tabular}

For the indirect classification by $\mathrm{CO}_{2}$-based constant ventilation $(\mathrm{CV})$, the constant rate obtained is 6.1 ACH (dashed yellow line) from 8:00 to 15:00. The number of occupants in the classroom is reduced in the evening and the ventilation rate decreases accordingly, due to the reduction in $\mathrm{CO}_{2}$ levels. $\mathrm{A}$ constant ventilation rate of 4.6 ACH is therefore applied from 16:00 to 20:00. 
For the indirect classification by $\mathrm{CO}_{2}$-based optimized demand control (VV), that is, with a variable ventilation rate, values range between 3.3 and $6.1 \mathrm{ACH}$ (dashed red line), corresponding to the variation of indoor-monitored $\mathrm{CO}_{2}$ levels in the classroom.

It can be seen that between 8:00 and 13:00, indoor $\mathrm{CO}_{2}$ concentrations are above the IAQ levels recommended by RITE (the grey shading represents a band of $500 \mathrm{ppm}$ over outdoor carbon dioxide levels). After 13:00, $\mathrm{CO}_{2}$ levels are reduced, meeting the IAQ comfort band and requiring a lower ventilation rate. This is due to the decrease in the number of occupants.

As regards the technical configuration of the system, Figure 10 represents a conceptual and simplified scheme of the proposed ventilation system. Mechanical fans would be incorporated in an air handling unit (AHU) placed on the roof of the building. Ventilation ducts would be located in the common corridor, supplying and extracting air though wall ventilation grids, as indicated in the mentioned figure.

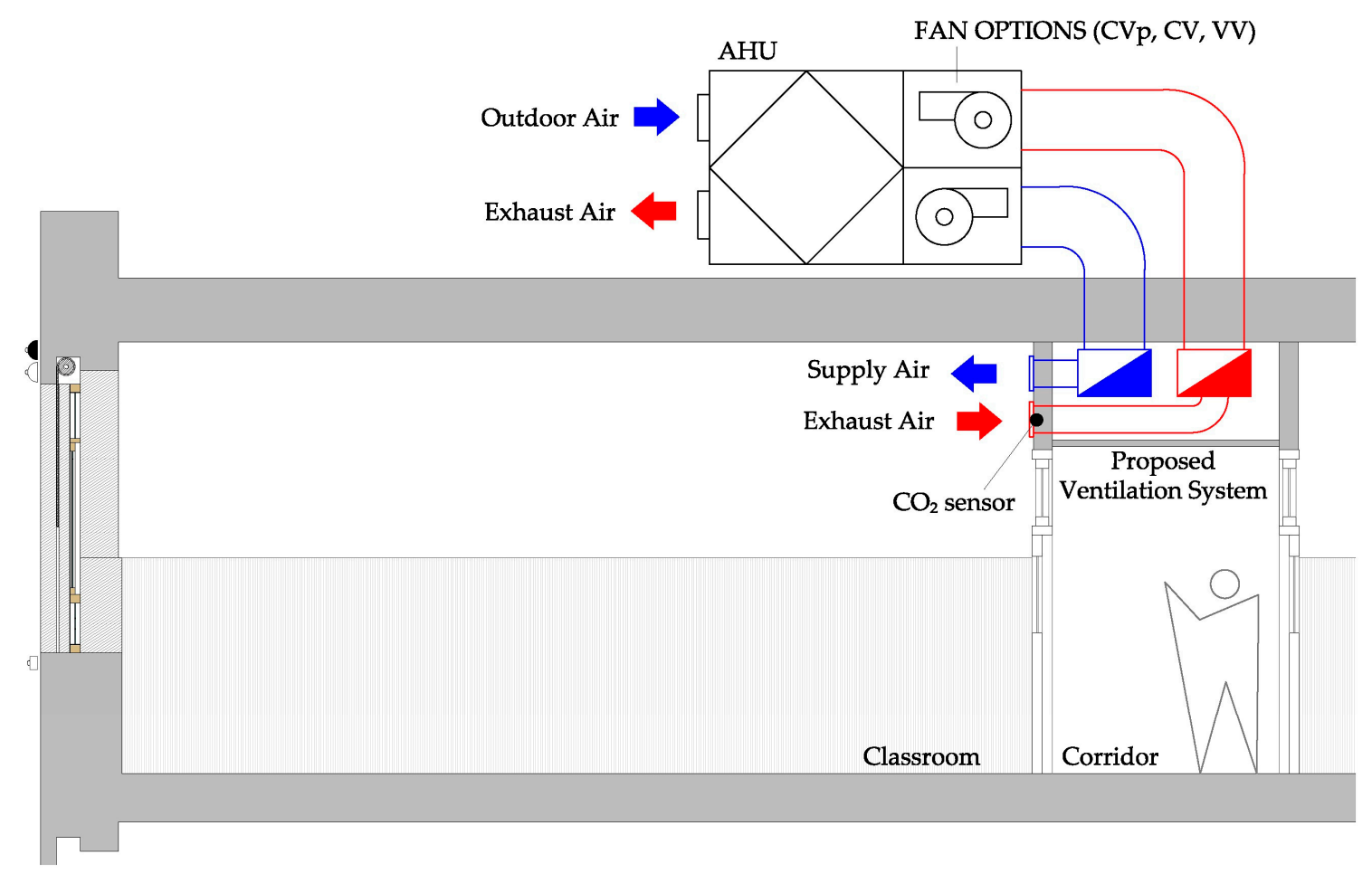

Figure 10. Scheme of the proposed ventilation system. Air handling unit (AHU) that incorporates the mechanical fans working at a constant (CVp and $\mathrm{CV})$ and variable (VV) rate.

\subsection{Ventilation Scenarios: Indoor Temperature Analysis}

In this section, the influence of the three ventilation scenarios analyses on the indoor temperatures of the classroom during free-running conditions were assessed (Figure 11). Their impact on indoor thermal comfort was analyzed in winter, summer, and mid-season.

The percentage of comfort hours was determined considering the academic year when the school is occupied, shown in Table 7. Based on both the indirect classification by the rate of outdoor air per person $(\mathrm{CVp})$ and the indirect classification by $\mathrm{CO}_{2}$-based constant ventilation $(\mathrm{CV})$, it can be observed that indoor temperatures are quite similar during the three seasonal periods. This also leads to similar percentages of comfort hours, with differences of around $0.6 \%$ in winter, $0.2 \%$ in summer, and $0.1 \%$ in mid-season, and a lower number of comfort hours in the case of the indirect classification by the rate of outdoor air per person $(\mathrm{CVp})$. In the third case, that of the indirect classification by $\mathrm{CO}_{2}$-based optimized demand control (VV), the number of thermal comfort hours is slightly lower than those of the other two scenarios. However, the differences are once again slightly noticeable, with $8.8 \%$ to $9.4 \%$ less thermal comfort hours in winter, $1.5 \%$ to $1.6 \%$ in summer, and $5.2 \%$ to $6.1 \%$ in mid-season. 


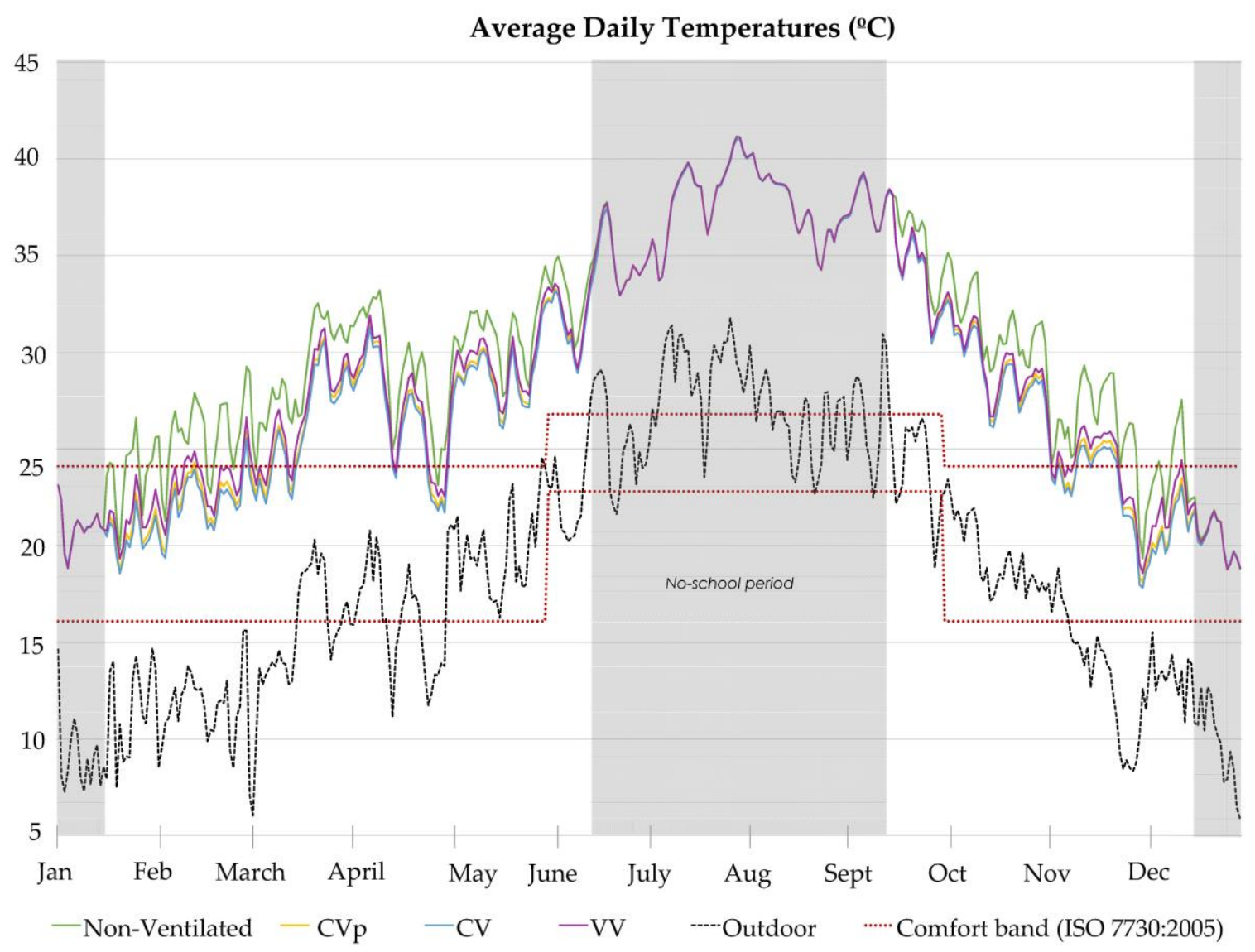

Figure 11. Comparison of indoor annual temperatures simulated in the three ventilation scenarios: indirect classification by the rate of outdoor air per person $(\mathrm{CVp})$, indirect classification by $\mathrm{CO}_{2}$-based constant ventilation $(\mathrm{CV})$, and indirect classification by $\mathrm{CO}_{2}$-based optimized demand control (VV).

Table 7. Simulation results: \% of thermal comfort hours in winter, summer, and mid-season.

\begin{tabular}{ccccccc}
\hline Protocols & $\begin{array}{c}\text { Comfort Hours in } \\
\text { Winter }\end{array}$ & \multicolumn{2}{c}{$\begin{array}{c}\text { Comfort Hours in } \\
\text { Summer }\end{array}$} & \multicolumn{2}{c}{$\begin{array}{c}\text { Comfort Hours in } \\
\text { Mid-Season }\end{array}$} \\
\hline Description & Hours & $\%$ & Hours & $\%$ & Hours & $\%$ \\
\hline Non-ventilated & 1500 & 69.4 & 43 & 1.2 & 367 & 10.0 \\
\hline CVp & 1929 & 89.3 & 122 & 3.3 & 806 & 21.9 \\
\hline CV & 1942 & 89.9 & 127 & 3.5 & 837 & 22.8 \\
\hline VV & 1739 & 80.5 & 68 & 1.9 & 614 & 16.7 \\
\hline Total school hours analyzed & 1872 & 86.7 & 1511 & 41.1 & 2663 & 72.5 \\
\hline Total no-school hours & 288 & 13.3 & 2161 & 58.9 & 265 & 7.2 \\
\hline Total hours & 2160 & 100.0 & 3672 & 100.0 & 2928 & 100.0 \\
\hline
\end{tabular}

Nevertheless, in all three cases, the thermal comfort percentages reached with no thermal treatment of the air are higher than those of the non-ventilated protocol, which represents the current state of the classroom.

\subsection{Ventilation Scenarios: Electrical Consumption Analysis}

Figure 12 shows the annual electricity consumption (kWh) associated to each ventilation system, based on the scenarios analyzed. 


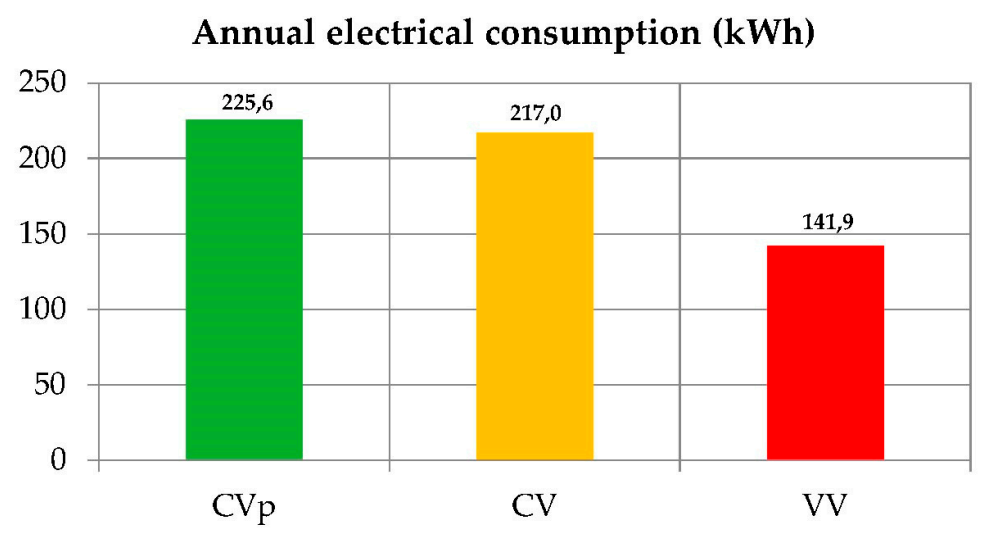

Figure 12. Comparison of annual electricity consumption in the three ventilation scenarios: indirect classification by the rate of outdoor air per person $(\mathrm{CVp})$, indirect classification by $\mathrm{CO}_{2}$-based constant ventilation $(\mathrm{CV})$, and indirect classification by $\mathrm{CO}_{2}$-based optimized demand control (VV).

As the results obtained show, the electricity consumption of a ventilation system operating in the classroom at a constant ventilation rate during the whole year, and determined by the indirect classification by the rate of outdoor air per person $(\mathrm{CVp})$, is around $225.6 \mathrm{kWh} /$ year. If a ventilation system calculated using $\mathrm{CO}_{2}$-based constant ventilation $(\mathrm{CV})$ is chosen, the electricity consumption is reduced by $3.8 \%\left(217.0 \mathrm{kWh} /\right.$ year). In contrast, the ventilation system determined using $\mathrm{CO}_{2}$-based optimized demand control (VV) allows electricity savings of $34.6 \%$, when compared to the previous option, with a total annual consumption of around $141.9 \mathrm{kWh} /$ year.

\section{Conclusions}

This paper assessed the indoor air quality (IAQ) of an educational building in southern Spain, analyzing the $\mathrm{CO}_{2}$ concentrations monitored in a classroom during a whole year. This research was conducted during three representative periods (winter, summer, and mid-season), comparing the registered values with the upper limits recommended by several national and international standards. In order to obtain $\mathrm{CO}_{2}$ reference values in the classroom in free-running conditions (no internal gains and windows totally closed), an unoccupied 5-day period was also analyzed. Taking into consideration the $\mathrm{CO}_{2}$ levels monitored, three ventilation scenarios were defined in order to compare their influence on the classroom's indoor temperatures (\% of thermal comfort hours) and on the electricity consumption of the ventilation system ( $\mathrm{kWh} / \mathrm{year}): 1)$ Indirect classification by the rate of outdoor air per person (CVp); (2) indirect classification by $\mathrm{CO}_{2}$-based constant ventilation (CV); and (3) indirect classification by $\mathrm{CO}_{2}$-based optimized demand control (VV).

The main conclusions reported in this research can be summarized as follows:

- During the unoccupied period and with the windows totally closed, the $\mathrm{CO}_{2}$ concentrations monitored in the classroom are below $425 \mathrm{ppm}$.

- When the classroom is occupied, in around $45 \%$ of the hours in winter and mid-season, carbon dioxide levels are between 500 and $1000 \mathrm{ppm}$, concentrations that are registered during $40 \%$ of the hours in summer.

- However, indoor $\mathrm{CO}_{2}$ levels are significantly high when the classroom is occupied in thermal comfort conditions, even exceeding values of $1500 \mathrm{ppm}$ in more than half of the analyzed hours in winter.

- Even though the classroom has natural ventilation mechanisms (windows), the high $\mathrm{CO}_{2}$ values justify the need to promote mechanical ventilation systems, guaranteeing indoor environmental quality in line with the requirements and recommendations of the national and international standards. The ineffectiveness of the natural ventilation mechanisms may be due to the lack of crossed-side ventilation and inadequate operation of these systems by users. 
- If the three ventilation scenarios are compared from a thermal point of view, $\mathrm{CO}_{2}$-based constant ventilation reaches approximately $15 \%$ more comfort hours per year in free-running conditions compared to $\mathrm{CO}_{2}$-based optimized demand ventilation, with more significant differences in winter. Nevertheless, indoor temperatures are quite similar between the ventilation based on outdoor air per person and the $\mathrm{CO}_{2}$-based constant ventilation for all the seasonal periods.

- When the associated electricity consumption is taken into account, differences between the three systems are much more noticeable: $\mathrm{CO}_{2}$-based optimized demand ventilation allows annual savings of around $35 \%$ in comparison with $\mathrm{CO}_{2}$-based constant ventilation. Moreover, $\mathrm{CO}_{2}$-based optimized demand ventilation consumes $40 \%$ less electricity per year than a ventilation based on outdoor air per person.

Despite its impact on thermal comfort, in an educational building located in the Mediterranean climate, the use of $\mathrm{CO}_{2}$-based optimized demand ventilation leads to very significant savings compared to other constant rate ventilation systems.

The results also show that high ventilation rates should be adopted in the case study to enhance IAQ conditions. In this sense, it should be highlighted that the ventilation rates established in the standards considered in this paper provide minimum values. Further research is required on this topic, especially regarding the consideration of how other pollutants may influence IAQ conditions. This paper shows how passive mechanical ventilation systems (without thermally treating air) can be used to retrofit Andalusian schools, improving IAQ conditions with a low electricity consumption.

Author Contributions: Á.L.L.-R. and R.S. conceived and designed the experiments; all authors performed the experiments; all authors analyzed the data; all authors have written, reviewed, and approved the final manuscript.

Funding: This research was funded by the Spanish government through the research and development project "Energy Rehabilitation of tertiary buildings in Mediterranean climate by optimizing Solar Protection Systems" (ref BIA2014-53949-R). Ministry of Economy and Competitiveness, Spanish Government. European Regional Development Fund. C.M.C.-G. wishes to acknowledge the financial support provided by the FPU Program of the Spanish Ministry of Education, Culture and Sport (FPU17/01375).

Conflicts of Interest: The authors declare no conflict of interest. The founding sponsors had no role in the design of the study; in the collection, analyses, or interpretation of data; in the writing of the manuscript, and in the decision to publish the results.

\section{References}

1. Eurostat. Statistical Books. In Energy Balance Sheets 2015 Data; Eurostat: Luxembourg, 2017. Available online: https://ec.europa.eu/eurostat/documents/3217494/8113778/KS-EN-17-001-EN-N.pdf (accessed on 25 June 2019).

2. Da Graça Carvalho, M. EU energy and climate change strategy. Energy 2012, 40, 19-22. [CrossRef]

3. Directive 2010/31/EU of the European Parliament and of the Council of 19 May 2010. On the Energy Performance of Buildings. Available online: https:/eur-lex.europa.eu/legal-content/EN/TXT/?uri=CELEX\% 3A32010L0031 (accessed on 25 June 2019).

4. Attia, S.; Carlucci, S. Impact of different thermal comfort models on zero energy residential buildings in hot climate. Energy Build. 2015, 102, 117-128. [CrossRef]

5. Ma, Z.; Cooper, P.; Daly, D.; Ledo, L. Existing building retrofits: Methodology and state-of-the-art. Energy Build. 2012, 55, 889-902. [CrossRef]

6. Schibuola, L.; Scarpa, M.; Tambani, C. $\mathrm{CO}_{2}$ based ventilation control in energy retrofit: An experimental assessment. Energy 2018, 143, 606-614. [CrossRef]

7. Directive 2012/27/EU of the European Parliament and of the Council of 25 October 2012. On Energy Efficiency. Available online: https://eur-lex.europa.eu/legal-content/EN/TXT/?uri=CELEX\%3A32012L0027 (accessed on 25 June 2019).

8. Directive Directive 2018/844/EU of the European Parliament and of the Council of 30 May 2018, Amending Directive 2010/31/EU on the Energy Performance of Buildings and Directive 2012/27/EU on Energy Efficiency. Available online: https:/eur-lex.europa.eu/legal-content/ES/TXT/?uri=CELEX\%3A32018L0844 (accessed on 25 June 2019). 
9. Santamouris, M.; Kolokotsa, D. On the impact of urban overheating and extreme climatic conditions on housing, energy, comfort and environmental quality of vulnerable population in Europe. Energy Build. 2015, 98, 125-133. [CrossRef]

10. Stazi, F.; Tomassoni, E.; Di Perna, C. Super-insulated wooden envelopes in Mediterranean climate: Summer overheating, thermal comfort optimization, environmental impact on an Italian case study. Energy Build. 2017, 138, 716-732. [CrossRef]

11. Parry, M.L.; Canziani, O.F.; Palutikof, J.P.; Van der Linden, P.J.; Hanson, C.E. IPCC 2007: Contribution of Working Group II. Fourth Assessment Report of the Intergovernmental Panel on Climate Change; Cambridge University Press: Cambridge, UK; New York, NY, USA, 2007.

12. Gil-Baez, M.; Padura, Á.B.; Huelva, M.M. Passive actions in the building envelope to enhance sustainability of schools in a Mediterranean climate. Energy 2019, 167, 144-158. [CrossRef]

13. Ministerio de Educación, Cultura y Deporte. Datos y Cifras. Curso Escolar 2015/2016; Secretaría General Técnica; Centro de Publicaciones: Madrid, Spain, 2015.

14. Gobierno de España, Presidencia del Gobierno. Real Decreto 2429/1979, de 6 de Julio, por el que se Aprueba la Norma Básica de Edificación NBE-CT-79, Sobre Condiciones Térmicas en los Edificios; Gobierno de España: Madrid, España, 1979. Available online: https://www.boe.es/boe/dias/1979/10/22/pdfs/A24524-24550.pdf (accessed on 2 December 2019).

15. Lizana, J.; Serrano-Jimenez, A.; Ortiz, C.; Becerra, J.A.; Chacartegui, R. Energy assessment method towards low-carbon energy schools. Energy 2018, 159, 310-326. [CrossRef]

16. Stabile, L.; Buonanno, G.; Frattolillo, A.; Dell'Isola, M. The effect of the ventilation retrofit in a school on CO2, airborne particles, and energy consumptions. Build. Environ. 2019, 156, 1-11. [CrossRef]

17. Krawczyk, D.A. Theoretical and real effect of the school's thermal modernization-A case study. Energy Build. 2014, 81, 30-37. [CrossRef]

18. Junta de Andalucía. Programa de Climatización Sostenible y Eficiencia Energética de Centros Escolares Públicos en Andalucía; Junta de Andalucía: Sevilla, España, 2017. Available online: https://www.juntadeandalucia.es/ export/drupaljda/planes/18/05/01\%20Programa\%20climatizaci\%C3\%B3n\%20completo.pdf (accessed on 25 June 2019).

19. De Giuli, V.; Da Pos, O.; De Carli, M. Indoor environmental quality and pupil perception in Italian primary schools. Build. Environ. 2012, 56, 335-345. [CrossRef]

20. Wargocki, P.; Wyon, D. Research report on effects of HVAC on student performance. Am. Soc. Heat. Refrig. Air Cond. Eng. ASHRAE J. 2006, 48, 23-28.

21. Tham, K.W. Indoor air quality and its effects on humans-A review of challenges and developments in the last 30 years. Energy Build. 2016, 130, 637-650. [CrossRef]

22. Mendell, M.J.; Eliseeva, E.A.; Davies, M.M.; Spears, M.; Lobscheid, A.; Fisk, W.J.; Apte, M.G. Association of classroom ventilation with reduced illness absence: A prospective study in California elementary schools. Indoor Air 2013, 23, 515-528. [CrossRef] [PubMed]

23. Wargocki, P.; Wyon, D.P. Providing better thermal and air quality conditions in school classrooms would be cost-effective. Build. Environ. 2013, 59, 581-589. [CrossRef]

24. Bakó-Biró, Z.; Clements-Croome, D.J.; Kochhar, N.; Awbi, H.B.; Williams, M.J. Ventilation rates in schools and pupils' performance. Build. Environ. 2012, 48, 215-223. [CrossRef]

25. Smedje, G.; Norback, D.; Edling, C. Mental performance by secondary school pupils in relation to the quality of indoor air. In Proceedings of the 7th International Conference on IAQ and Climate-Indoor Air, Nagoya, Japan, 21-26 July 1996; pp. 413-419.

26. Myhrvold, A.N.; Olsen, E.; Lauridsen, O. Indoor environments in schools-pupils health and performance in regard to $\mathrm{CO}_{2}$ concentrations. In Proceedings of the 7th International Conference on IAQ and Climate-Indoor Air, Nagoya, Japan, 21-26 July 1996; pp. 369-374.

27. Shendell, D.G.; Prill, R.; Fisk, W.J.; Apte, M.G.; Blake, D.; Faulkner, D. Associations between classroom $\mathrm{CO}_{2}$ concentrations and student attendance in Washington and Idaho. Indoor Air 2004, 14, 333-341. [CrossRef]

28. Branco, P.T.B.S.; Alvim-Ferraz, M.C.M.; Martins, F.G.; Sousa, S.I.V. Quantifying indoor air quality determinants in urban and rural nursery and primary schools. Environ. Res. 2019, 176, 108534. [CrossRef]

29. Becerra, J.A.; Lizana, J.; Gil, M.; Barrios-Padura, A.; Blondeau, P.; Chacartegui, R. Identification of potential indoor air pollutants in schools. J. Clean. Prod. 2020, 242, 118420. [CrossRef] 
30. Lazović, I.; Jovašević-Stojanović, M.; Živković, M.M.; Tasic, V.; Stevanović, Ž.M. PM and $\mathrm{CO}_{2}$ variability and relationship in different school environments. Chem. Ind. Chem. Eng. Q. 2015, 21, 179-187. [CrossRef]

31. American Society of Heating, Refrigerating and Air Conditioning Engineers. 62.1: Ventilation for Acceptable Indoor Air Quality; ASHRAE: Atlanta, GA, USA, 2013.

32. European Committee for Standardization. CEN 15251:2007. Indoor Environmental Input Parameters for Design and Assessment of Energy Performance of Buildings-Addressing Indoor Air Quality, Thermal Environment, Lighting and Acoustics; European Committee for Standardization: Brussels, Belgium, 2007.

33. Homod, R.Z.; Sahari, K.S.M.; Almurib, H.A.F. Energy saving by integrated control of natural ventilation and HVAC systems using model guide for comparison. Renew. Energy 2014, 71, 639-650. [CrossRef]

34. Van Hooff, T.; Blocken, B.; Timmermans, H.J.P.; Hensen, J.L.M. Analysis of the predicted effect of passive climate adaptation measures on energy demand for cooling and heating in a residential building. Energy 2016, 94, 811-820. [CrossRef]

35. Dorizas, P.V.; Assimakopoulos, M.-N.; Helmis, C.; Santamouris, M. An integrated evaluation study of the ventilation rate, the exposure and the indoor air quality in naturally ventilated classrooms in the Mediterranean region during spring. Sci. Total Environ. 2015, 502, 557-570. [CrossRef] [PubMed]

36. Calama-González, C.M.; Suárez, R.; León-Rodríguez, Á.L.; Ferrari, S. Assessment of Indoor Environmental Quality for Retrofitting Classrooms with an Egg-Crate Shading Device in a Hot Climate. Sustainability 2019, 11, 1078. [CrossRef]

37. UNE-EN. 16798-3:2018 Energy Performance of Buildings_Ventilation for Buildings_Part 3: For Non-Residential Buildings-Performance Requirements for Ventilation and Room-Conditioning Systems (Modules M5-1, M5-4); AENOR: Madrid, Spain, 2018.

38. Griffiths, M.; Eftekhari, M. Control of $\mathrm{CO}_{2}$ in a naturally ventilated classroom. Energy Build. 2008, 40, 556-560. [CrossRef]

39. Stabile, L.; Dell'Isola, M.; Frattolillo, A.; Massimo, A.; Russi, A. Effect of natural ventilation and manual airing on indoor air quality in naturally ventilated Italian classrooms. Build. Environ. 2016, 98, 180-189. [CrossRef]

40. Wang, Y.; Zhao, F.-Y.; Kuckelkorn, J.; Liu, D.; Liu, L.-Q.; Pan, X.-C. Cooling energy efficiency and classroom air environment of a school building operated by the heat recovery air conditioning unit. Energy 2014, 64, 991-1001. [CrossRef]

41. Almeida, R.M.S.F.; de Freitas, V.P. IEQ Assessment of Classrooms with an Optimized Demand Controlled Ventilation System. Energy Procedia 2015, 78, 3132-3137. [CrossRef]

42. The Mathworks Inc. MATLAB R2017a Software; The Mathworks Inc.: Natick, MA, USA, 2017. Available online: https://es.mathworks.com/products/matlab.html (accessed on 2 December 2019).

43. RITE. Spanish Standard for Thermal Installations in Buildings (Reglamento de Instalaciones Térmicas de los Edificios); Ministry of Industry, Energy and Turism, Spanish Government: Madrid, Spain, 2013.

44. American Society of Heating, Refrigerating and Air-Conditioning Engineers. ASHRAE Guideline 14-2002: Measurement of Energy and Demand Savings; ASHRAE: Atlanta, GA, USA, 2002.

45. CEN European Technical Report CR 1752. Ventilation for Buildings: Design Criteria for the Indoor Environment; European Committee for Standardization: Brussels, Belgium, 1998.

46. Calama-González, C.M.; Suárez, R.; León-Rodríguez, Á.L. Thermal and Lighting Consumption Savings in Classrooms Retrofitted with Shading Devices in a Hot Climate. Energies 2018, 11, 2790. [CrossRef]

47. International Organization for Standardization. ISO 7726:2002. Ergonomics of the Thermal EnvironmentInstruments for Measuring Physical Quantities; ISO: Geneva, Switzerland, 2002.

48. U.S. Department of Energy (DOE), Washington, DC, USA. 2017. Available online: http://www.energy.gov (accessed on 15 December 2018).

49. U.S Department of Energy. EnergyPlus Energy Simulation Software; US Department of Energy: Washington, DC, USA, 2017. Available online: http://apps1.eere.energy.gov (accessed on 15 December 2018).

50. International Organization for Standardization. ISO 7730:2005 (E). Ergonomics of the Thermal Environment-Analytical Determination and Interpretation of Thermal Comfort Using Calculation of the PMV and PPD Indices and Local Thermal Comfort; ISO: Geneva, Switzerland, 2005.

51. Fanger, P.O. Thermal Comfort: Analysis and Applications in Environmental Engineering; Danish Technical Press: Copenhagen, Denmark, 1970. 
52. European Committee for Standardization. CEN/TC 156. prEN 16798-1:2015. Energy Performance of Buildings_-Part 1: Indoor Environmental Input Parameters for Design and Assessment of Energy Performance of Buildings Addressing Indoor Air Quality, Thermal Environment, Lighting and Acoustics-Module M1-6; European Committee for Standardization: Brussels, Belgium, 2015.

53. American Society of Heating, Refrigerating and Air Conditioning Engineers. ANSI/ASHRAE 55-2017: Thermal Environmental Conditions for Human Occupancy; ASHRAE: Atlanta, GA, USA, 2017.

54. Soler \& Palau Ventilation Systems. Mixed Flow Duct Fans with Brushless DC Motors of High Efficiency and Low Consumption. Available online: http://www.solerpalau.co.uk/ (accessed on 10 June 2019).

55. International Organization for Standardization. Thermal Performance of Buildings-Determination of Air Permeability of Buildings_Fan Pressurization Method ISO 9972; ISO: Geneva, Switzerland, 2015.

56. Sherman, M.H. Estimation of infiltration from leakage and climate indicators. Energy Build. 1987, 10, 81-86. [CrossRef]

57. Calama-González, C.M.; Suárez, R.; León-Rodríguez, Á.L.; Domínguez-Amarillo, S. Evaluation of Thermal Comfort Conditions in Retrofitted Facades Using Test Cells and Considering Overheating Scenarios in a Mediterranean Climate. Energies 2018, 11, 788. [CrossRef]

(C) 2019 by the authors. Licensee MDPI, Basel, Switzerland. This article is an open access article distributed under the terms and conditions of the Creative Commons Attribution (CC BY) license (http://creativecommons.org/licenses/by/4.0/). 